\title{
Serum Alanine Aminotransferase Measurement
}

National Cancer Institute

\section{Source}

National Cancer Institute. Serum Alanine Aminotransferase Measurement. NCI

Thesaurus. Code C61017.

A quantitative measurement of the amount of alanine aminotransferase present in a sample of serum. 